\title{
DAR DUCHA ŚWIĘTEGO I JEGO IMPLIKACJE ETYCZNE DLA WSPÓLNOTY KOŚCIOŁA NA PODSTAWIE DZ 2, 1-41
}

W zgodnej opinii biblistów „Łukasz jest ewangelistą Ducha Świętego” oraz „Dzieje Apostolskie są "ewangelią Ducha Swiętego"”. Cytat wprowadzający do zaproponowanej tu analizy zagadnienia: Dar Ducha Świętego i jego implikacje etyczne na podstawie $\mathrm{Dz} 2$, 1-41, zaczerpnięty został z monografii Introduzione all'opera di Luca. Aspetti teologici Giovanniego Claudia Bottiniego², oferującej również dobre syntetyczne ujęcie tematu Ducha Swiętego w podwójnym dziele Łukasza. W trzeciej Ewangelii uprzywilejowanym posiadaczem i nosicielem Ducha Świętego jest Jezus, natomiast w Dziejach Apostolskich Duch Święty jest darem eschatologicznym dla nowej wspólnoty, Kościoła. Związek pomiędzy Duchem a Jezusem ukazany w pierwszej Łukaszowej księdze stanowi fundament relacji pomiędzy Duchem Świętym a Kościołem w drugiej ${ }^{3}$.

Drugi rozdział Dziejów Apostolskich, przedmiot podjętej w artykule analizy, „jest uprzywilejowanym miejscem dla Łukaszowej teologii Ducha Świętego”. Warto już we wstępie zaznaczyć także - za przywołanym wyżej autorem - mocne zakorzenienie pneumatologii Łukasza w tradycji biblijnej. Ten związek z objawieniem Starego Testamentu sytuuje autora Dziejów Apostolskich z dala od środowiska

\footnotetext{
G.C. Bottini, Introduzione all'opera di Luca. Aspetti teologici, Milano 2011, s. 139.

Por. tamże, s. 139-160.

Analiza pneumatologii Dziejów Apostolskich zaproponowana przez Bottiniego koncentruje się na roli Ducha Świętego w życiu wspólnoty chrześcijańskiej, sprowadzającej się w istocie do: prowadzenia działalności misyjnej i ewangelizacyjnej Apostołów oraz ich współpracowników; asystencji w czasie prześladowań Kościoła i wspierania wspólnoty uczniów Jezusa w dawaniu świadectwa; bycia darem obiecanym lub udzielonym dla wszystkich wierzących; związku Ducha Swiętego z modlitwą. Por. tamże, s. 141.

4 S. DYк, Duch, Stowo, Kościót. Biblijny model ewangelizacji, Lublin 2007, s. 22.
} 
hellenistycznego, chroniąc tym samym przed niebezpieczeństwem wypaczenia obrazu Ducha Świętego w pojęciach właściwych dla religijności pogańskiej jego czasu (tj. Duch Święty jako emanująca moc bóstwa $)^{5}$.

Podjęte w tytule zagadnienie przedstawimy w trzech punktach, uwzględniając przy tym strukturę Łukaszowej narracji. W punkcie pierwszym, poświęconym opowiadaniu o wydarzeniu zesłania Ducha Świętego (Dz 2, 1-13), ukażemy, iż fenomen Pięćdziesiątnicy jest w teologii Dziejów Apostolskich otwarciem grupy pierwszych uczniów Jezusa Zmartwychwstałego - przemienionej dzięki wylaniu Ducha Świętego w Kościół - na nieznany im do tej pory język, znak i zewnętrzny przejaw nowego serca, które stworzył w uczniach Duch Święty, źródło nowej kreatywnej komunikacji z odmiennością drugiego. W punkcie drugim skoncentrujemy się na trzech kolejnych etapach mowy pentekostalnej Piotra (Dz 2, 14-41) przedstawiającej teologiczne i zbawcze znaczenie Pięćdziesiątnicy jako: inaugurację nowej epoki (Dz 2, 15-21), owoc Paschy Jezusa (Dz 2, 22-36) oraz wezwanie do udzielenia odpowiedzi na dar „z wysoka” w akcie nawrócenia i przyjęcia chrztu w Imię Jezusa (Dz 2, 37-41). Implikacjom etycznym - w Łukaszowym ujęciu - wynikającym z odpowiedzi ucznia Zmartwychwstałego Pana na dar Ducha Świętego poświęcimy trzeci, ostatni punkt niniejszego artykułu.

\section{Pięćdziesiątnica jako dar Ducha Świętego dla nowej WSPÓLNOTY: $\mathrm{DZ} 2, \mathrm{I}-\mathrm{I} 3$}

Pierwszy rozdział Dziejów Apostolskich - którego celem jest połączenie trzeciej Ewangelii z tą księga ${ }^{6}$ - stanowi jednocześnie wprowadzenie do rozdziału drugiego, tematyczne przejście od czasów Jezusa do czasów Kościoła. Chrystofanie Zmartwychwstałego Pana zakończyły się wraz z Jego Wniebowstąpieniem (por. Dz 1, 9-11). W Jerozolimie zgromadziła się wokół grupy jedenastu Apostołów pierwsza wspólnota uczniów. Następnie ma miejsce - dokonane przed przyjściem Ducha Świętego, w znamienny sposób, bo za pomocą losu i w oparciu o związek z Jezusem historycznym - uzupełnienie o Macieja grona Dwunastu (Dz 1, 15-26). Wszystko jest zatem

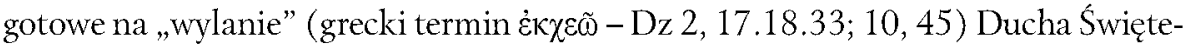

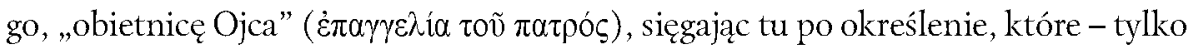
w pismach Łukaszowych - Chrystus wypowiada do uczniów przed Wniebowstąpieniem (por. Łk 24, 49; Dz 1, 4-5.8) .

Por. G.C. BotTini, Introduzione all'opera di Luca, s. 159.

Por. S. Dyk, Duch, Stowo, Kościót. Biblijny model ewangelizacji, s. 20.

Por. A. JankowskI, Duch Święty Dokonawca zbawienia. Nowy Testament o posłannictwie eschatologicznym Ducha Świętego, Kraków 2003, s. 7. 
Realizacja „obietnicy Ojca”, zesłanie Ducha Świętego stanowiło moment fundamentalny dla pierwotnej wspólnoty chrześcijańskiej, ponieważ dzięki niemu dokonała się transformacja w Kościół grupy pierwszych uczniów Jezusa. Łukasz przedstawia to wydarzenie ${ }^{8}$ w obszernej i bogatej teologicznie narracji (Dz 2, 1-41). Z łatwością wyróżnić można dwie części tego opowiadania. Wersety od 1 do 13 zawierają opis zesłania Ducha Świętego w dwóch scenach: ww. 1-4, zstąpienie Ducha, oraz ww. 5-13, cud języków. Dalsza narracja od wersetu 14 do 41 to mowa pentekostalna Piotra (Dz 2, 14-36) $)^{9}$, która wyjaśnia teologiczne i zbawcze znaczenie zrelacjonowanej historii, doświadczenia wiary wspólnoty chrześcijańskiej przypisane wydarzeniu Pięćdziesiątnicy, a w zakończeniu referuje reakcję świadków na słowo Apostoła ( $\mathrm{Dz} 2,37-41)$.

\section{1. „Prawo Ducha” dla „nowego Izraela”}

Jak to wyraźnie wyakcentowano w wersecie pierwszym, zesłanie Ducha Świętego rozgrywa się w święto Pięćdziesiątnicy: „Kiedy nadszedł wreszcie dzień Pięćdziesiąt-

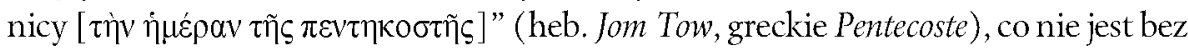
znaczenia dla teologicznej treści cudu. W tym dniu Żydzi obchodzili jedno z najważniejszych dorocznych świąt związanych z pielgrzymką do Jerozolimy. Nazywali je Pięćdziesiątnicą, ponieważ obchodzone było pięćdziesiąt dni po święcie Paschy. Tradycja opierała się w tym wypadku na Księdze Wyjścia 19, 1, według której Izraelici stanęli u stóp Synaju i otrzymali tam Prawo i Przymierze (por. także Pwt 16, 9). Pięćdziesiąt dni po odprawieniu pierwszej Paschy żydowskiej i wyjściu z niewoli egipskiej Bóg na górze Synaj zawarł z ludem izraelskim Przymierze ${ }^{10}$. Izraelici otrzymali wtedy także Prawo, dlatego uważali, iż jest ono darem, za który należy dziękować. Żydowskie święto Pięćdziesiątnicy przypominało więc dar Prawa, „konstytucji” udzielonej na Synaju wyzwolonemu z Egiptu ludowi Bożemu. Łukasz z pewnością znał religijne konotacje tego żydowskiego święta i świadomie się we wstępie opowiadania do nich odwołał, aby wyeksponować teologiczną wymowę wydarzenia zesłania Ducha Świętego, jaką były narodziny nowej społeczności, nowego Izraela, Kościoła.

8 Wspólnym przekonaniem pierwszych chrześcijan jest związek pomiędzy odejściem Jezusa i darem Ducha Świętego (por. J 15, 26-16, 7; 20, 21-22), a także umiejscowienie Ducha u źródeł wiary (1 Kor 12, 3; Ga 3, 2; 1 J 3, 24). W pismach Nowego Testamentu tylko autor Dziejów Apostolskich ukazuje zesłanie Ducha w dniu Pięćdziesiątnicy jako akt fundacyjny wspólnoty wierzących. Por. D. Marglierat, Gli Atti degli apostoli, t. 1: 1-12, Bologna 2011, s. 77.

9 Wydarzenie Pięćdziesiątnicy przedstawione w Dziejach przez Łukasza zawiera wiele analogii do życia Jezusa z jego Ewangelii. Początki Kościoła podobne są do początków życia i działalności Jezusa: mowa w Nazarecie jest programowym manifestem działalności Jezusa ( $Ł k$ 4, 14-30), mowa jerozolimska Piotra „manifestem programowym misji Kościoła”. Łukasz ukazuje w ten sposób, że Kościół kontynuuje misję Jezusa i prowadzi ją na Jego wzór. Por. S. DYk, Duch, Stowo, Kościót. Biblijny model ewangelizacji, s. 21-22.

10 Dlatego np. w Qumran było to już tylko święto Przymierza Boga z Izraelem. Odnawiano wtedy przymierze z Bogiem i przyjmowano nowych członków do zgromadzenia. 
Wyrażenie „wszyscy razem na tym samym miejscu” (w. 1) określa miejsce, gdzie rozegrało się wylanie Ducha. Najprawdopodobniej chodziło o Wieczernik, który od czasu męki Pańskiej stał się zwyczajnym miejscem spotkań wyznawców Chrystusa. Jednak słowa „wszyscy razem”" 11 odnoszą się przede wszystkim do wydarzeń, które miały miejsce w czasie proklamowania Prawa na Synaju. W tedy lud Izraela obozował razem i mówił jednogłośnie: „Uczynimy wszystko, co Pan nakazał” (Wj 19, 8). Fakt ten mocno akcentowała tradycja judaistyczna, która wyjaśniała przywołany wiersz w następujący sposób: „Izrael obozował naprzeciw góry zjednoczony sercem”. Tanaici-najstarsi świadkowie tradycji rabinackiej - twierdzili, że Izraelici w chwili przybycia pod Synaj „czuli jedno sercem” i dlatego ,jednogłośnie” odpowiedzieli Mojżeszowi, zobowiązując się do zachowania słowa Boga. Trzeba o tym pamiętać, czytając Łukaszowy wstęp do opisu zesłania Ducha Świętego. Wynika z niego bowiem, że autor Dziejów akcentuje fakt, iz jedność niewielkiej grupy uczniów Jezusa, wspólnoty Kościoła w dniu Pięćdziesiątnicy, odpowiada zgodności zgromadzenia Izraela u stóp Synaju. Zatem werset wprowadzający do narracji eksponuje myśl, że w klimacie podobnym do tego, jaki panował pod Synajem, rodzi się nowa społeczność, nowy lud Boży, „stworzony jako eschatologiczne wznowienie zgromadzenia spod Synaju" ${ }^{12}$.

Należy wszakże odnotować istotną różnicę pomiędzy dwoma wyżej wskazanymi społecznościami. Żydowska Pięćdziesiątnica, skoncentrowana na darze Tory - jak zauważyliśmy wyżej - była także wspomnieniem obietnicy Nowego Przymierza, zapowiedzianej między innymi przez proroka Jeremiasza (Jr 31, 31-33) oraz Ezechiela ${ }^{13}$ : "I dam wam serce nowe i ducha nowego tchnę do waszego wnętrza, odbiorę wam serce kamienne, a dam wam serce z ciała. Ducha mojego chcę tchnąc w was i sprawić, byście żyli według mych nakazów i przestrzegali przykazań, i według nich postępowali" (Ez 36, 26-27). Zdaniem Daniela Marguerata,

autor Dziejów Apostolskich był czuły na punkcie potencjału teologicznego święta. Wykorzystał go [ potencjał teologiczny Pięćdziesiątnicy] dla swojej periodyzacji historii zbawienia, ponieważ umożliwiał mu on uwyraźnienie nowego etapu:

11 S. Dyk zwrócił uwage, iż przymiotnik ónoṽ, który oznacza „razem”, a w połączeniu z $\tilde{\eta} \sigma a v$ (znaj-

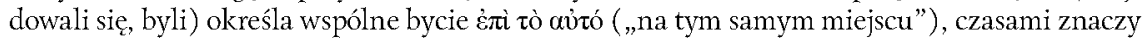
„należeć do siebie”, tzn. przebywać razem ze względów emocjonalnych, jednomyślnie. Por. tenże, Duch, Stowo, Kościót. Biblijny model ewangelizacji, s. 51.

12 Tamże, s. 62.

13 Liczne teksty Starego Testamentu zawierają obietnicę daru Ducha Świętego w czasach mesjańskich i eschatologicznych: Iz 32, 15-20 zapowiada wylanie Ducha w Jerozolimie; Ez 36, 26-27 wylanie Ducha w sercu człowieka, a 39, 29 na dom Izraela; Zach 12, 10 wylanie Ducha na dom Dawida i Jerozolimę. W pisuje się w tę linię tematyczną również tekst J1 3, 1-5 zapowiadający „dzień Pana", którego pierwszą manifestacją będzie uniwersalne wylanie Ducha, a towarzyszyć mu będą znaki z nieba. Po tekst Joela sięgnie Łukasz, czyniąc go skrypturystycznym argumentem uzasadniającym rozpoczęcie zapowiedzianej przez Pisma nowej epoki zainaugurowanej wydarzeniem Pięćdziesiątnicy. Zagadnienie to będzie przedmiotem naszej analizy w punkcie 1.2. Por. G.C. BoTTINI, Introduzione all'opera di Luca, s. 128-129. 
zesłanie Ducha Świętego przypieczętowującego odnowienie przymierza Boga ze swoim ludem. W ten sposób zaznaczony został w narracji wymiar fundacyjny Pięćdziesiątnicy chrześcijańskiej ${ }^{14}$.

Wydaje się więc rzeczą oczywistą, iż to odniesienie biblijne jest fundamentalne dla zrozumienia teologicznej głębi Łukaszowego opowiadania o chrześcijańskiej Pięćdziesiątnicy. Uczniowie otrzymują Ducha Świętego, który przyjmuje cechy nowego Prawa, niespisanego już na kamiennych tablicach, ale w sercach (por. Jr 31, 33). Nowy lud „w Nowym Przymierzu będzie się rządził zapowiedzianym przez proroków "nowym sercem", "nowym duchem", gdyż "Prawo «będzie miał już zapisane "w głębi jestestwa« (Ez 36, 26 n.; Jr 31, 33)"15. Odtąd bowiem Prawo nie będzie już - jak było w przypadku Izraela - wypisane na kamiennych tablicach, ale sam Duch Święty będzie obecny w sercach wierzących w Chrystusa. On uczyni z małej grupy uczniów wspólnotę - Kościół. Prawo nie będzie już spisane w formie kodeksu, Duch Święty obdarzy też wierzących umiejętnością komunikowania się w całkowicie nowy sposób.

W tym kontekście dobrze będzie przywołać spostrzeżenie Daniela Marguerata:

Tomasz z Akwinu wydobywa teologię Eukasza, gdy stwierdza: ,Jak święto Paschy zastępuje święto Paschy i zmartwychwstania Chrystusa, podobnie święto Pięćdziesiątnicy - podczas którego podarowano starożytne Prawo - zastępuje Pięćdziesiątnica, w czasie której podarowane zostało prawo Ducha życia (lex spiritus vitae)" (STh I-II, q. 103, a. 3) ${ }^{16}$.

Dodajmy, iż w encyklice Jana Pawła II Veritatis splendor życie moralne chrześcijanina ukazane zostało jako kierowane przez „Prawo Ducha” (nr 22-23, 45). Za Jego sprawą "prawo zostaje zapisane w naszym wnętrzu, tak że możemy je postrzegać i przeżywać jako dynamikę prawdziwej osobowej wolności”, jako „doskonałe Prawo, Prawo wolności (Jk 1, 25)" (nr 83).

\subsection{Dar przywracający jedność pomiędzy ludźmi}

Celem zilustrowania realności i teologicznego waloru zesłania Ducha Świętego Łukasz przedstawia je za pomocą obrazów i klasycznych biblijnych symboli, wykorzystując znany w Starym Testamencie teofaniczny gatunek literack $\mathrm{i}^{17}$. Temu wydarzeniu - jak czytamy w ww. 2-3 - towarzyszyły dwa zjawiska zmysłowe, audiowizualne: szum wichru (audycja) oraz ukazanie się języków jakby z ognia (wizja).

14 D. Marguerat, Gli Atti degli apostoli, t. 1: 1-12, s. 80 (tłum. własne).

15 A. Jankowski, Zarys pneumatologii Nowego Testamentu, Kraków 1982, s. 31.

16 D. Marguerat, Gli Atti degli apostoli, t. 1: 1-12, s. 83.

17 Por. S. Dyк, Duch, Stowo, Kościót. Biblijny model ewangelizacji, s. 30-31, 49. 
Tekst przywołuje najpierw zjawisko gwałtownego wiatru. Z opisu widać, że autor opowiadania miał niemałą trudność $w$ przedstawieniu tego fenomenu akustycznego. Łukasz nie pisze bowiem, że był to rzeczywisty wiatr, ale że szumiało, ,jakby” ( $\ddot{\omega} \sigma \pi \varepsilon \rho)$ wiał gwałtowny wiatr. Ponieważ chodzi o niezwykłe wydarzenie, dlatego redaktor tekstu może posłużyć się jedynie niewystarczającymi porównaniami, przestrzegając przed dosłownym rozumieniem zjawiska i wskazując na jego boskie pochodzenie. Dobrze jest zauważyć, że pojawiający się tu grecki rzeczownik $\pi v$ o (wiatr) ma wspólny źródłosłów ze słowem $\pi v \varepsilon v ́ \mu \alpha$ (duch): obydwa pochodzą od czasownika $\pi v \varepsilon ́ \omega$ (tchną́, wiać). Opis ten przywodzi na pamięć słowa Księgi Rodzaju o stwórczym tchnieniu Boga, porządkującym pierwotny chaos. Jak wyjaśniał Jan Paweł II w encyklice Dominum et Vivificantem,

To biblijne pojęcie stworzenia oznacza nie tylko powołanie do istnienia samego bytu wszechświata: czyli obdarowanie istnieniem - oznacza ono również obecność Ducha Bożego w stworzeniu [...]. Odnosi się to przede wszystkim do człowieka, który został stworzony na obraz i podobieństwo Boga ${ }^{18}$.

Słowo to określa w tej samej księdze Biblii tchnienie wiatru, które powoli kładło kres potopowi $(\mathrm{Rdz} 8,1)$. W opowiadaniu tym termin $\pi v 0 \eta$ zwiastuje nowe życie, które weźmie początek z ocalonych ludzi sprawiedliwych. Podobna sytuacja ukazana została w Księdze Wyjścia. Przed Izraelitami uchodzącymi śpiesznie z Egiptu „Pan cofnął wody gwałtownym wiatrem wschodnim. [...] Wody się rozstąpiły" (Wj 14, 21). Także w symbolicznej wizji ożywienia wyschłych kości prorok Ezechiel zapisze: „Z czterech wiatrów przybądź, duchu, i powiej na tych pobitych, aby ożyli" (Ez 37, 9). Dla Hebrajczyka zakorzenionego $w$ tradycji biblijnej znak wichru mówił zatem o wielorakim życiodajnym i twórczym działaniu Boga. To zewnętrzne zjawisko akustyczne towarzyszące zesłaniu Ducha - w świetle reminiscencji biblijnych - jest dla autora Dziejów tylko obrazem rzeczywistości innej, niewypowiedzianej ${ }^{19}$. Symbol wiatru wskazuje, że Pięćdziesiątnica to „ożywiające wkroczenie Ducha jako Mocy Bożej w dzieje dopiero co ukształtowanego Kościoła"20.

W przekrojowej analizie zagadnienia posłannictwa eschatologicznego Ducha Świętego w Nowym Testamencie, opatrzonej tytułem Duch Święty Dokonawca zbawienia, Augustyn Janowski przedstawia mozaikowy obraz poszczególnych etapów powtarzania w Starym Testamencie „obietnicy Ojca” zapowiadającej zesłanie Ducha. Bardzo cenne dla naszej analizy - ukierunkowanej na implikacje etyczne daru Ducha Świętego - jest w tej pracy uwyraźnienie procesu przemiany moralnej jako charakterystycznego następstwa Jego przyszłego wylania.

18 Jan Pawę II, Encyklika Dominum et Vivificantem o Duchu Świętym w życiu Kościoła i świata, Rzym 1986, nr 12.

19 Por. A. JANKowskI, Zarys pneumatologii Nowego Testamentu, s. 31.

20 Tamże. 
Na pierwszej karcie Pisma Duch Boży (Tchnienie Boże) ma udział w akcie stwórczym, porządkując pierwotny chaos ( $\operatorname{Rdz} 1,2)$. Następnie daje On szansę nowemu życiu, kończąc niszczące działanie potopu $(\operatorname{Rdz} 8,1)$, a u początku wyjścia z Egiptu niesie Izraelowi wybawienie, rozcinając przed ludem wody Morza Czerwonego (Wj $14,21 ; 15,9.10)^{21}$.

Interesujący nas aspekt „tylko od Boga zależnej przemiany moralnej człowieka”, której sprawcą będzie obiecany Duch, jest wyraźny w zapowiedziach prorockich na czasy mesjańskie. Za pośrednictwem Ezechiela Bóg obiecuje oczyszczenie moralne Izraela, którego dokona przyszłe wylanie Ducha (Ez 36, 25-27). „Nowy duch” ożywiający "nowe serce” ludu Bożego będzie wówczas ,immanentną obecnością Ducha Bożego”. Proces przemiany moralnej- jako skutek przyszłego działania Ducha Ojca - dokładniej kreśli Deutero-Zachariasz (Zach 12,10). Duch obiecany przez Ojca „sprawi, że łaska umożliwi przebłaganie" grzesznej przeszłości Izraela. Odrodzenie moralne za Jego sprawą ukazuje jeszcze bardziej sugestywnie symboliczna wizja Ezechiela (Ez 37, 1-14), obraz zmartwychwstania całego narodu. Wreszcie za pośrednictwem Joela (J1 3, 1-2) pada eschatologiczna obietnica, iż cała ludzkość otrzyma dary Ducha ${ }^{22}$. Właśnie ona posłuży Piotrowi - w przemówieniu, które będzie przedmiotem naszej analizy (punkt 2.1) - jako dowód nastania czasów mesjańskich w wydarzeniu Pięćdziesiątnicy, w której zrealizuje się obietnica Ojca.

Temu słyszalnemu fenomenowi towarzyszy - co podkreśla Eukasz - zjawisko optyczne, dostępne świadkom wydarzenia wzrokowo: „ukazały się im też rozdzielające się

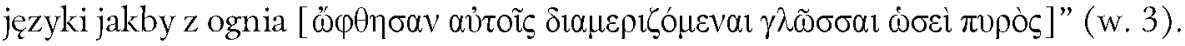
Należy przypomnieć, iż w tradycji biblijnej ogień jest znakiem obecności i mocy Boga (Wj 3, 2; 19, 18). Bóg przemawiał z ognia (Pwt 4, 12) i z ognia przekazywał tablice Prawa (Pwt 9, 10). Prorok Malachiasz porównuje dzień przyjścia Boga do ognia, który stapia wszystko i wypala, oczyszcza srebro i synów Lewiego (Ml 3, 2-3). Tę symbolikę przeją i pogłębił Nowy Testament. Jan Chrzciciel zapowiadał, że Mesjasz, który nadejdzie, będzie chrzcit „Duchem Świętym i ogniem” (Łk 3, 16; Mt 3, 11). Znak ognia zostaje tu wyraźnie złączony z Duchem Świętym. Ogień, podobnie jak wcześniej wiatr, jest więc znakiem epifanii Boga mającej miejsce w Wieczerniku. Łukasz pisze o „rozdzielających się językach jakby z ognia". Precyzuje przez to, że nie był to rzeczywisty ogień, ale zjawisko go przypominające. Realizujące się w Wieczerniku misterium epifanii Ducha Świętego pozostaje nieuchwytne, nie do opisania, nie daje się zamknąć w ludzkich pojęciach. Tajemnicę obecności Tego, który jest nieogarniony, kryje sformułowanie , jakby z ognia”. Redaktor Łukasz pozwala dzięki temu zrozumieć, iż Apostołowie byli w Wieczerniku świadkami zjawiska nadprzyrodzonego (por. Łk 1, 11; 22 , 43 ; 24, 34; Dz 7, 2.30.35; 9, 17; 26, 16; por. 1 Kor 15, 5-8), co uwydatnia jeszcze bar-

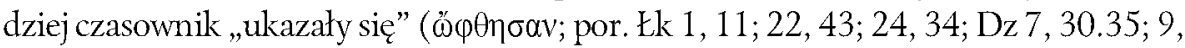

21 Por. A. Jankowski, Duch Święty Dokonawca zbawienia, s. 9-12.

22 Por. tamże, s. 19-22. 
17; 26, 16; także 1 Kor 15, 5-8). Łukasz posługuje się jego stroną bierną, „zostało im

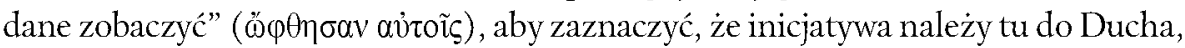
który przychodzi, objawia się i działa w sposób całkowicie wolny ${ }^{23}$.

Autor Dziejów zaakcentował w tym samym trzecim wersecie, iż ,języki jakby

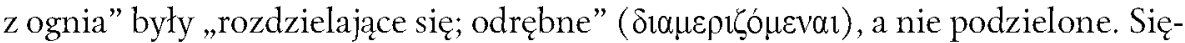

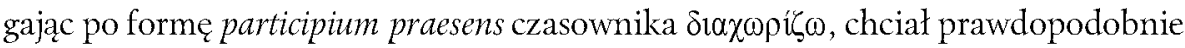
podkreślić sposób działania Ducha Świętego, który łączy, zespala rozdzielone narody i języki, przywracając pierwotną jedność między ludźmi zniszczoną przez ich

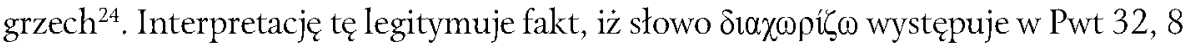
we wzmiance o rozdzieleniu narodów: „Kiedy Najwyższy rozgraniczał narody [LXX:

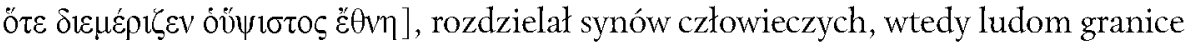
wytyczył [...]" (por. Dz 17, 26). Jest to niewątpliwie także pośrednia aluzja do biblijnego opowiadania o rozdzieleniu języków przy budowie wieży Babel z Rdz 11, 1-9, a potwierdzi to jeszcze wyraźniej odniesienie do tego wydarzenia w dalszej Łukaszowej narracji o Pięćdziesiątnicy, gdy będzie mowa o darze mówienia „obcymi językami” (w. 4) oraz reakcji wzbudzonej wylaniem Ducha w Dz 2, 5-13. W wydarzeniu Pięćdziesiątnicy Eukasz zamierza więc podkreślić - posługując się paralelizmem antytetycznym - początek powrotu do jedności ludu Bożego, naprawę historii wieży Babel, przyczyny rozproszenia. Jak słusznie jednak zauważa Daniel Marguerat, Pięćdziesiątnica nie przywraca jednego języka, lecz uznaje za cud fakt, iż Duch mówi wszystkimi językami. Wydarzenie zaprasza więc do tego, aby rozróżnić jedność Słowa w różnorodności języków. Pięćdziesiątnica nie ustanawia komunikacji zunifikowanej, lecz daje obietnicę, iż Duch potrafi zamieszkać każdą kulturę ${ }^{25}$. Wnioskiem natury teologicznej opowiadania $\mathrm{Dz} 2,5-13$ jest więc twierdzenie, że dar Ducha Swiętego, Jego działanie jednoczy ludzi, stwarza z nich nową jednośćc ${ }^{26}$. Warto zaznaczyć za Łukaszem, iż jedność Kościoła jest dziełem Ducha Świętego, nie tworzy się jej, lecz otrzymuje „z nieba” (Dz 2,2).

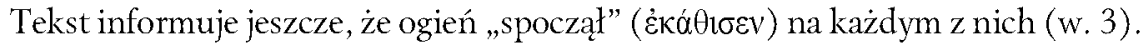
Czasownik grecki sugeruje trwałe wzięcie na własność każdego z Apostołów przez zesłanego Ducha Świętego ${ }^{27}$. Oznacza to, iż te języki wchodzą w sposób osobowy w obecnych tak, by każdy czuł się w pełni sobą, a zarazem przeniknięty przez Ducha Świętego. Jezus udziela Ducha, szanując indywidualność i wewnętrzną wrażliwość każdego z uczniów.

23 Podobnie było przy objawieniu się Zmartwychwstałego uczniom: On sam „dał się im poznać” (por. Łk 24,35).

24 Por. S. Dyк, Duch, Stowo, Kościót. Biblijny model ewangelizacji, s. 55.

25 Por. D. Marguerat, Gli Atti degli apostoli, t. 1: 1-12, s. 90.

26 Por. S. Dyк, Duch, Stowo, Kościôt. Biblijny model ewangelizacji, s. 67.

27 Por. A. Jankowski, Zarys pneumatologii Nowego Testamentu, s. 32-33. 
Analizując Łukaszowy opis epifanii Ducha w dniu Pięćdziesiątnicy, nie wolno nam pominąc nowotestamentowych odniesień. Szum pochodzący z nieba jest bowiem podobny do głosu rozbrzmiewającego w czasie chrztu Jezusa (Mk 1, 11; Mt 3, 17; Łk 3, 22), do głosu usłyszanego przez Piotra w Jafie (Dz 11,9) i tego, który dociera do widzącego w Apokalipsie (Ap 10, 4.8; 11, 12; 14, 2.13; 18, 4). Autor Dziejów Apostolskich zapowiada w ten sposób, „k to będzie kierował losami tego przedłużenia Chrystusa, jakim jest Kościól"28. Dodajmy, iż Łukasz - znawca Starego Testamentu - naśladuje tu „styl biblijny”, aby uwyraźnić czytelnikowi, że wylanie Ducha Świętego należy interpretować jako nowy Synaj, odpowiedź na żydowskie oczekiwanie Nowego Przymierza zawartego na fundamencie tego Ducha, którego obiecał Bóg (por. Ez 36, 36). Nie bez słuszności komentatorzy $\mathrm{Dz} 2,1-6$, zauważając podobieństwo do słownictwa narracji o Synaju, wyrażają przekonanie, iż Łukasz odnalazł w teofanii synajskiej ramy interpretacyjne pierwszego wylania Ducha Świętego na Kościót ${ }^{29}$.

\subsection{Dar otwierający na komunikację i spotkanie z odmiennością drugiego}

Werset 4 opisu zesłania Ducha przechodzi od języka symboli do wyjaśnienia teologicznego. Wyjątkowe wydarzenie epifanijne przedstawione w ww. 2-3 zostaje teraz zinterpretowane teologicznie: „wszyscy zostali napełnieni Duchem Świętym”. Zdanie to wskazuje, że wcześniej opisane zjawiska zmysłowe były tylko materialnym, zewnętrznym przejawem czegoś niezmiernie ważnego: zstąpienia Ducha Świętego na zebranych, napełnienia ich mocą Bożą. Należy zauważyć, iż czasownik ė $\pi \lambda \eta \dot{\sigma} \sigma \eta \eta \sigma v$ (zostali napełnieni) użyty tu został w greckim aoryście (w. 4). Forma gramatyczna wskazuje, iż chodzi o wydarzenie jednorazowe, którego skutki trwają w teraźniejszości. Aoryst podkreśla, że dar Ducha pozostaje, działa w życiu wierzących, uzdalniając ich do głoszenia Ewangelii.

Duch Święty, który został udzielony, będzie od tej chwili stale działał w Kościele, aby kierować jego misją, uzdalniając Apostołów do powierzonego im zadania dawania świadectwa. Duch Święty jest nowością eschatologiczną, która od tej chwili będzie zawsze charakteryzować egzystencję uczniów ${ }^{30}$.

\footnotetext{
28 Tamże, s. 29.
}

29 „Język typowy dla starotestamentalnych epifanii nie umniejsza jednak realności opisywanego wydarzenia, lecz służy do oddania trudnej i nieuchwytnej rzeczywistości zesłania Ducha Swiętego". S. Dyk, Duch, Stowo, Kościót. Biblijny model ewangelizacji, s. 58.

30 G. Rossé, Atti degli Apostoli commento esegetico e teologico, Roma 1998, s. 132. Łukasz będzie stale przypominał w Dziejach tę prawdę: napełnieni Duchem Świętym są Piotr (Dz 4, 8), Apostołowie (Dz 4, 31), Szczepan (Dz 6, 5; 7, 55), Paweł (Dz 9, 17; 13, 9), Barnaba (Dz 11, 24), uczniowie (Dz 13, 52). 
Jednym ze skutków zstąpienia Ducha Świętego, szczególnie wyeksponowanym przez Łukasza, jest „mówienie językami” (w. 4). Z jednej strony autor Dziejów stara się podkreślić działanie łaski Boga, która sprawia, iż proklamacja Ewangelii dociera do ludów i zostaje przez nich przyjęta. $Z$ drugiej zaś, w perspektywie narracji o Pięćdziesiątnicy, Łukaszowa koncepcja „mówienia językami” ma wyjątkowy charakter. Działanie słowa, które jest owocem Ducha Świętego, zostaje tu zdefiniowane nie tylko jako zrozumiałe mówienie profetyczne (por. w 11 b: „głoszą w naszych językach wielkie dzieła Boże", co zakłada umiejętność proklamowania Ewangelii narodom), ale również mówienie obcymi językami (dodatek ě̃cpoৎ̧ wskazuje na obce języki ${ }^{31}$ ) być może już tutaj zwraca uwagę na późniejszą proklamację o charakterze misyjnym $^{32}$. W opinii włoskiego biblisty Gérarda Rossé,

Intencja opowiadania Łukasza jest teologiczna. [ ... ] To, co zostaje tutaj uwypuklone, to fakt, iż u fundamentu życia Kościoła jest eschatologiczny dar Ducha Świętego, przyczyna pierwsza wszystkich nadzwyczajnych zjawisk, jakich mogła doświadczyć wspólnota. Łukasz przypomina tu swój projekt literacki, ukierunkowuje czytelnika na uniwersalizm zbawczy, któremu służy głoszenie Ewangeliii ${ }^{33}$.

Warto przywołać w tym miejscu także opinię francuskiego biblisty Daniela Marguerata, który stwierdza: „Duch Święty otwiera uczniów na różnorodność, na język do tej pory im nieznany, język, który jest źródłem nowej komunikacji. Dar innych języków udziela uczniom zebranym wokół Apostołów kreatywnej mocy komunikacji”34. Duch Święty, uzdalniając wierzących do „mówienia językami”, znosi więc bariery między ludźmi i przyczynia się do ich jedności ${ }^{35}$. Stanisław Dyk, autor cennej na polskim gruncie monografii poświęconej $\mathrm{Dz} 2,1-47$, opowiada się za interpretacją misyjną tego wydarzenia. W opinii tego lubelskiego teologa dar Ducha Swiętego „pozwala Apostołom i misjonarzom chrześcijańskim głosić identyczną Ewangelię Chrystusa w kulturze różnych narodów i języków. Duch daje Kościołowi możliwość i zdolność "mówienia "[...] w języku i kulturze wszystkich narodów"36. Nowy język, o którym pisze tu Łukasz, jest więc znakiem i zewnętrznym przejawem nowego serca, które stworzył w uczniach Duch Święty. Przełamali oni barierę własnego języ-

31 Glosolalię, tj. ekstatyczną mowę w niezrozumiałym języku (aniołów: por. np. 1 Kor 13, 1), Eukasz zamienia w ksenolalię, mówienie obcymi językami. W interpretacji trzeciego ewangelisty dar Ducha Swiętego uzdalnia Apostołów do świadectwa (Dz 1, 8; 2, 14-36) wobec słuchaczy z wszystkich narodów. Por. R. PESCH, Die Apostelgeschichte (Apg 1-12) (EKK 5/1), Neukirchen-Vluyn -Zürich 1986, s. 104.

32 Por. G. Rossé, Atti degli Apostoli commento esegetico e teologico, s. 133.

33 Tamże (tłum. własne).

34 D. Marguerat, Gli Atti degli apostoli, t. 1: 1-12, s. 84 (tłum. własne).

35 Por. S. Dyк, Duch, Stowo, Kościót. Biblijny model ewangelizacji, s. 45.

36 Tamże, s. 61. 
ka, symbolu wszelkich granic dzielących ludzi: rasowych, kulturowych, klasowych, mentalnych i majątkowych ${ }^{37}$.

\section{Perspektywa teologiczna daru Ducha Świętego: Dz 2, i5-4I}

Przemówienie Piotra, które następuje po opisie wylania Ducha Świętego, zredagowane zostało przez Łukasza ( $\mathrm{Dz} 2,14-41)$ i służy jako odpowiedź na pytania i fałszywe interpretacje wydarzeń Pięćdziesiątnicy dokonywane przez niektóre współczesne mu środowiska ${ }^{38}$. Mowa zawiera tematy fundamentalne orędzia pierwszej wspólnoty chrześcijańskiej i teologiczne, które zostały w niej wyjaśnione. Cała jej treść rozwinięta została w oparciu o cytaty i uzasadnienie biblijne (Jl 3, 1-5 w ww. 16-21; Ps 16 w ww. 8-11; Ps 110, 1 w ww. 34b-35), możliwe i skuteczne jedynie w środowisku żydowskim, wymagającym zawsze dowodu ,według Pisma”. Zatem Piotr interpretuje fenomen Pięćdziesiątnicy, czytając Pisma w świetle wydarzenia paschalnego Chrystusa.

Przemówienie ma charakter programowy w Dziejach Apostolskich: świadcząo tym jego umiejscowienie w tekście, długość oraz uroczysty charakter. Jest ono pierwszą publiczną proklamacją Ewangelii, a także pierwszym orędziem skierowanym do Żydów oraz uzewnętrznieniem autorytetu apostolskiego Piotra. Odpowiada przemówieniu inaugurującemu publiczną działalność Jezusa w synagodze w Nazarecie (Łk 4, $16-$ 30). Podobnie jak tamto, jest też pełne odniesień do Pisma, cytatów i historii Izraela. Widoczny jest więc paralelizm skonstruowany przez Łukasza pomiędzy początkiem działalności Jezusa (chrzest - przemówienie w Nazarecie - uzdrowienia) a początkami Kościoła (Pięćdziesiątnica - przemówienie inauguracyjne - uzdrowienia).

\subsection{Inauguracja nowej epoki: $\mathrm{Dz} 2,15-21$}

Pierwsza część mowy Piotra to relektura historii prorockiej. Interpretacja teologiczna, skrypturystyczna i profetyczna cudu Pięćdziesiątnicy dokonuje się w niej w oparciu o obszerny cytat obietnicy z Księgi Joela 3, 1-5, której autorstwo przypisuje się prorokowi z IV wieku przed Chr. Łukasz cytuje wersię grecką LXX, modyfikując ją w niektórych miejscach ${ }^{39}$. Odniesienie to służy intencji teologicznej redaktora,

37 Por. R Cantalamessa, Tajemnica Pięćdziesiątnicy, Wrocław 2002, s. 10.

38 Dzisiejsza hermeneutyka każe rozpoznać w tej narracji odniesienie do doświadczenia odrzucenia i szyderstwa z Kościoła w czasach Łukasza.

39 Różnice pomiędzy tekstem Jl i Dz dotyczą: w. 17a: „mówi Bóg”; w. 17a: „w ostatnich dniach” Pięćdziesiątnica inauguruje ostatnią fazę historii (LXX ma „po tym”; w. 18b: „będą prorokowali” - Eukasz akcentuje wymiar profetyczny zadania uczniów; w. 18a: ,na niewolników i niewolnice moje" - służących zmienia w wierzących w Boga). Chodzi o obietnice, która ma charakter

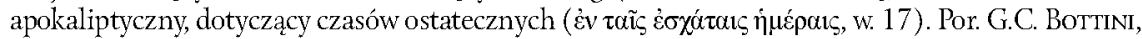
Introduzione all opera di Luca, s. 129. 
wskazaniu, że Pięćdziesiątnica jest wydarzeniem eschatologicznym, zapowiedzianą odnową całego Izraela. Proroctwo Joela jest więc kluczem interpretacyjnym do zstąpienia Ducha Świętego: w nim realizuje się to, co zostało zapowiedziane na „ostatnie dni” (w. 17). Łukasz przedstawia Pięćdziesiątnicę jako inaugurację „nowej epoki”, epoki „ostatnich dni”, którą charakteryzować będzie wylanie daru Ducha na liczne osoby $^{40}$. Tekst i kontekst historyczny Księgi proroka Joela nie zostawiają miejsca na wątpliwości: obietnica daru Ducha Świętego dotyczy mieszkańców Jerozolimy i Judei, to znaczy Żydów. Należy wszakże zauważyć, iż perspektywa Łukasza jest zdecydowanie inna. Dlatego nie jest rzeczą przypadku, iż autor zakończył cytat z Joela na pierwszej części wersetu 5: „Każdy, kto wzywać będzie imienia Pańskiego, będzie zbawiony” (Dz 2, 21), opuszczając J1 3, 5b: „bo na górze Syjon [i w Jeruzalem] będzie wybawienie, jak przepowiedział Pan, i wśród ocalałych będą ci, których wezwał Pan". Przyczyna tego opuszczenia wydaje się dwojaka: po pierwsze, tekst prorocki mówi w tym miejscu o ocaleniu od śmierci i zniszczenia tylko fizycznego; po drugie, zacieśnia on obszar zbawienia tylko do Jerozolimy i Syjonu. „Łukaszowi zależało na odblokowaniu propozycji zbawienia $z$ »domu Izraela $(\mathrm{Dz} 2,26)$ na »wszystkich w oddali« (Dz 2, 39), na "wszelkie ciało« (Dz 2, 17; por. Łk 3, 6 - cytat z Iz 40,5) w sensie uniwersalistycznego przeznaczenia zbawienia, tak dla Żydów, jak i pogan" ${ }^{11}$. Cytat z Księgi proroka Joela pozwala poza tym wprowadzić część centralną mowy, którą jest kerygmat chrystologiczny.

\subsection{Owoc Paschy Jezusa: $\mathrm{Dz} 2,22-36$}

Dziwić może fakt, iż pentekostalne przemówienie Piotra, które ma na celu interpretację, wyjaśnienie wydarzenia zesłania Ducha Świętego, jest tak bardzo chrystologiczne. Wersety 22-36 są w rzeczywistości kerygmatem. Zatem od pierwszej, pneumatologicznej części przemówienia przechodzi się do drugiej, chrystologicznej. W ten sposób Łukasz eksponuje, że wylanie Ducha Świętego na wspólnotę Kościoła jest skutkiem zmartwychwstania Jezusa, owocem Jego Paschy ${ }^{42}$. Rzeczywiście, zesłanie Ducha w dniu Pięćdziesiątnicy zakłada wywyższenie Jezusa, ponieważ Bóg powierzył Ducha Świętego uwielbionemu Synowi $(\mathrm{Dz} 2,33)^{43}$. Poprzez wylanie Ducha „dobra i błogosławieństwa nabyte przez Jezusa poprzez Jego śmierć, zmar-

40 Czasownik ,wylać” występuje często w Starym Testamencie w powiązaniu z wodą (por. Am 5, 8; 9, 6), a w sensie przenośnym używany jest w odniesieniu do Ducha (por. Ez 39, 29; Zach 12, 10). W tekście Jl 3, 1, do którego odwołuje się Łukasz w $\mathrm{Dz} 2,17$, termin ten wskazuje na boskie pochodzenie wylania Ducha i wyraża ideę dogłębnego przenikania, a przez to dużej skuteczności: Duch, podobnie jak woda, która wsiąka w ziemię, przenika głębię serca i ducha czlowieka. Por. S. Dyk, Duch, Stowo, Kościót. Biblijny model ewangelizacji, s. 76.

41 Tamże, s. 78. Por. także G.C. BotTini, Introduzione all'opera di Luca, s. 129.

42 „W dzień Pięćdziesiątnicy [...] Pascha Chrystusa wypełnia się przez wylanie Ducha Świętego, który zostaje objawiony, dany i udzielony jako Osoba Boska: Chrystus Pan ze swej pełni wylewa obficie Ducha”. KKK 731.

43 Por. D. Marguerat, Gli Atti degli apostoli, t. 1: 1-12, s. 109. 
twychwstanie i wniebowstąpienie zostały wyrażone i »zastosowane« do Apostołów i wszystkich wierzących" 44 . Łukasz przejmuje tu schemat starożytnego kerygmatu, sięga po tzw. schemat kontrastu obecny w najstarszej chrystologii. Ludzkiemu działaniu, które uśmierciło Jezusa, przeciwstawione jest działanie Boga, który wskrzesił Go z martwych. Formuła ta - wielokrotnie obecna w Księdze Dziejów (por. Dz 3, $13-$ $-15 ; 4,10 ; 5,30-31 ; 10,39-49 ; 13,27-30)$ - poświadcza wyższość aktu Boga, który wskrzesza Jezusa, nad działaniem ludzi, którzy Go zabili ${ }^{45}$. Z jednej strony, wspomina się w tej części mowy Piotra działalność Jezusa przed ukrzyżowaniem (jest to druga taka wzmianka w Dziejach Apostolskich, obok Dz 10, 36-39). Warto zauważyć, iż Apostoł wskazuje tu jako klucz interpretacyjny stałe odniesienie do działalności i życia Chrystusa. Czyny pełne mocy dokonane przez Nauczyciela z Nazaretu zostają zinterpretowane jako znaki troski Boga, których On sam dokonał przez pośrednictwo Jezusa dla dobra swojego ludu ${ }^{46}$. Z drugiej natomiast strony, jest tu mowa o tym, iż Jezus „z woli postanowienia i przewidzenia Bożego został wydany” (w. 23). To precyzuje, że Jego śmierć powinna być rozumiana teocentrycznie, jako konieczność ustanowiona w zbawczym planie Boga.

Cytat z Ps 16, 1-8 otwiera nowy aspekt w argumentacji (ww. 25-31). W hebrajskiej wersji Psalm 16 wyraża zaufanie psalmisty do Boga, który nie wystawi go na ryzyko przedwczesnej śmierci ( „nie zostawisz duszy mojej w Otchłani”, w. 27) oraz zrekonstruuje zagrożone przez nią życie ( „nie dasz Świętemu Twemu ulec skażeniu”, w. 27). Psalm artykułuje przekonanie wierzacego, iż Bóg nie pozostawi jego ciała na wieczność w Szeolu (gr. ås̄ৎ), lecz pozwoli mu poznać „drogi życia” (w. 28). To ostatnie sformułowanie zawiera wymiar eschatologiczny wskrzeszonego życia. Piotr reinterpretuje cytowany wcześniej Psalm $16^{47}$ jako wypowiedziany już przez samego Dawida dowód na zmartwychwstanie Jezusa (w. 31).

W centrum mowy Piotra na temat Jezusa znajduje się orędzie o Zmartwychwstaniu: „tego właśnie Jezusa wskrzesił Bóg”, które wpisane zostaje w nowy kontekst wierności Boga swojemu słowu. Następujace po tym odwołanie do proroctwa Natana umiejscawia zmartwychwstanie Jezusa w obietnicy danej przez Boga. Pojawia się także dodatkowy aspekt: „a my wszyscy jesteśmy tego świadkami” (w. 32). Oprócz dowodów z Pisma potwierdzeniem zmartwychwstania Jezusa jest przede wszystkim osobiste świadectwo Apostołów. Spotykamy tutaj fundamentalny temat Dziejów Apostolskich: świadectwo chrześcijańskie. Ono nie ogranicza się do potwierdzenia faktów (interwencja Boga w historii i jej doświadczenie przez Apostołów), lecz zawiera również interpretację (Apostołowie wyjaśniali wydarzenia paschalne jako

44 S. Dyк, Duch, Stowo, Kościót. Biblijny model ewangelizacji, s. 22.

45 Por. tamże, s. 81.

46 Por. A. CoRTeSI, Atti degli Apostoli oggi: una proposta di lettura in un'epoca di crisi, Firenze 2013, s. 76.

47 Czas przyszły w w. 27, który jest cytatem z Ps 16,10 , został w w. 31 zamieniony na aoryst. Użycie aorystu oznacza dokonanie się tego, co zostało wcześniej zapowiedziane. 
interwencję Boga, który wybawia Jezusa ze śmierci ${ }^{48}$. To działanie Boga wydobywające Chrystusa ze śmierci oraz Jego wywyższenie stały się przyczyną zesłania Ducha Świętego (w. 33).

W przemówieniu Piotra (jest ono przykładem orędzia chrześcijaństwa pierwotnego, które głosi wydarzenie Jezusa, czytając na nowo teksty starotestamentowe) możemy uchwycić centralność Zmartwychwstania w proklamowaniu wiary chrześcijańskiej. Rozumiane jest ono jako część planu Boga realizowanego w historii Izraela, w obietnicach danych ojcom i prorokom, zapowiedzianego w Psalmach, które interpretowane są w świetle wydarzenia Paschy Chrystusa. $Z$ przyjęcia tego orędzia wynika jednak - według narracji Łukasza - zasadnicze pytanie: „Cóż mamy czynić, bracia?" (w. 37), „Jak odpowiedzieć na ten dar Ducha Świętego?”. Apel podejmuje i informacji udziela ostatnia część przemówienia Piotra.

\subsection{Wezwanie do nawrócenia i przyjęcia chrztu: $\mathrm{Dz} 2,37-41$}

Końcowa część przemówienia Piotra (Dz 2, 37-41) ma charakter parenetyczny, jest wezwaniem do udzielenia odpowiedzi na usłyszane orędzie o zesłaniu Ducha

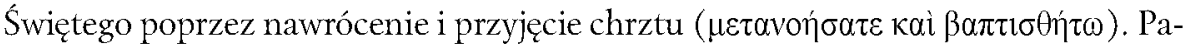
reneza ta zawiera cztery warunki dostępu do zbawienia: nawrócenie, chrzest, przebaczenie grzechów oraz dar Ducha Świętego.

Początek wezwania Piotra powtarza apel proroków do nawrócenia, rozumianego jako przemiana życia, postępowania i relacji względem Boga ${ }^{49}$. Użyte w w. 38

$\mu \varepsilon \tau \alpha v o \eta ́ \sigma \alpha \tau \varepsilon$ wyraża negatywny wymiar nawrócenia, czyli świadomość grzechu (por. Dz 2, 12.23.36) i gotowość porzucenia postępowania grzesznego. Chodzi więc tu przede wszystkim o odrzucenie negatywnych przekonań co do Jezusa, zwrócenie się ku Niemu i uznanie Go za Pana i Boga. Motywem tej radykalnej przemiany życia jest zmartwychwstanie Chrystusa ${ }^{50}$.

Warto zauważyć, iż termin „nawrócenie”, który ma dla etyki Łukasza istotne znaczenie, pojawia się tu po raz pierwszy w Dziejach. Wymagana zmiana ma być adekwatna do nowej propozycji zbawienia: każdy zostaje zaproszony do przyjęcia chrztu

48 Por. D. Marglierat, Gli Atti degli apostoli, t. 1: 1-12, s. 101-103.

49 Pierwsza część Łukaszowego podwójnego dzieła rozpoczyna się opisem działalności Jana Chrzciciela, który „głosił chrzest nawrócenia dla odpuszczenia grzechów”; Marek mówi w 1, 4 o kazaniu o nawróceniu Jana Chrzciciela, a w 1, 14 informuje, że Jezus powraca do Galilei i swoje przepowiadanie rozpoczyna od zawołania: „Nawracajcie się i wierzcie w Ewangelię!” (Mk 1, 15). Dzieje pokazują tu wyraźnie kontynuację pomiędzy początkami publicznej działalności Jezusa a początkami Kościoła, pomiędzy pierwszym wymaganiem przepowiadania o królestwie Bożym a pierwszym wymaganiem kazania Apostoła. Grecki czasownik metanoein oznacza zmianę myślenia i widzenia. Tradycyjne tlumaczenie „pokutować” wskazuje na to, że ci, którzy świadomi są swojej grzeszności, którzy wiedzą, że odwrócili się od Boga, muszą zmienić swój styl życia.

50 S. Dyк, Duch, Stowo, Kościót. Biblijny model ewangelizacji, s. 93. 
„w imię Jezusa Chrystusa”, co oznacza zbawcze działanie Zmartwychwstałego, wskazując na to, że chrzest udzielony nawracającemu się do Niego nie jest udzielany mocą człowieka (który chrzci) czy Kościoła, ale mocą samego Chrystusa.

Łukasz informuje następnie o dwóch skutkach, jakie niosą ze sobą nawrócenie i chrzest: $z$ jednej strony jest to przebaczenie grzechów (dla tłumu oznacza winę zaciągniętą przez ukrzyżowanie Pana), z drugiej natomiast dar Ducha. Piotr i jego towarzysze otrzymali Ducha Świętego, a teraz obiecują, że zostanie On dany wszystkim wierzącym. W chrześcijaństwie nie ma bowiem podziału na dwie klasy (por. Dz 10, 44-48: ta sama równość w otrzymaniu daru Ducha, gdy ochrzczeni zostaną pierwsi poganie). To będzie miało ogromne znaczenie dla rozpoczynającego się, zainaugurowanego wylaniem Ducha na Kościół w Jerozolimie dzieła ewangelizacji. Zakończmy ważnym, aktualizującym biblijną narrację spostrzeżeniem Józefa Kudasiewicza: w opinii tego biblisty Łukaszowy „opis zesłania Ducha zawiera niezwykle ważne i ciagle aktualne orędzie: chrzest dla wszystkich, którzy uwierzyli w Chrystusa, jest prawdziwą Pięćdziesiątnicą, tj. obdarowaniem Duchem Świętym"51.

\section{Implikacje etyczne daru Ducha ŚwiĘTego}

W ostatnim punkcie naszej analizy, dotyczącej orędzia Łukasza na temat daru Ducha Świętego zapisanego w narracji o Pięćdziesiątnicy, chcemy wskazać niek tóre jego aktualne implikacje etyczne. Z konieczności (ramy artykułu) kwestię tę musimy potraktować skrótowo, zakładając jej niekomplementarność. Wskażemy trzy - w naszej opinii najbardziej aktualne - implikacje etyczne daru Ducha Świętego według Łukaszowego ujęcia.

\section{1. „Czynić dobro”: synteza życia Jezusa i etyki chrześcijańskiej}

Pierwsza odpowiedź na pytanie świadków wydarzenia wylania Ducha Świętego: „Co mamy czynić, bracia?”, aby otrzymać dar największy, jakim jest zbawienie, prowadzi według przekazu Dziejów do uznania doniosłości fundamentalnego etycznego postępowania chrześcijan, polegającego na czynieniu dobra na wzór Jezusa. Wniosek ten jest oczywisty, kiedy weźmie się pod uwagę fragment Dziejów Apostolskich (inne przemówienie Piotra), w którym Łukasz podsumowuje życie Jezusa jako tego, który „przeszedł, czyniąc dobrze”:

Wiecie, co się działo w całej Judei, począwszy od Galilei, po chrzcie, który głosił Jan. Znacie sprawę Jezusa z Nazaretu, którego Bóg namaścił Duchem Swiętym i mocą. Dlatego że Bóg był z Nim, przeszedł On, dobrze czyniąc i uzdrawiając wszystkich, którzy byli pod władzą diabła (Dz 10, 37-38).

51 J. Kudasiewicz, Odkrywanie Ducha Swiętego. Medytacje biblijne, Kielce 1998, s. 233. 
Jezus „namaszczony Duchem Świętym” jest - poprzez swoje orędzie i czyny wzorem najwyższym w czynieniu dobra, paradygmatem etyki chrześcijańskiej.

\subsection{Los Jezusa paradygmatem dla ucznia i wspólnoty Kościoła}

Druga implikacja etyczna daru Ducha Świętego, jaką odnaleźć możemy w Łukaszowym przekazie, dotyczy losu Jezusa pojmowanego jako paradygmat historii życia ucznia i wspólnoty chrześcijańskiej. W oparciu o informacje z Dziejów Apostolskich wskazać można trzy aspekty tego paradygmatu: 1) Wniebowstąpienie jako wzór drogi Kościoła; 2) wybór niestosowania przemocy; 3) nowe spojrzenie i świadectwo.

W narracji $\mathrm{Dz}$ 1, 4-11 o Wniebowstąpieniu Łukasz proponuje swoje rozumienie teologiczne Zmartwychwstania, które w świetle wstąpienia Chrystusa do Ojca jawi się jako nowe życie Jezusa przekraczające śmierć (akt Wniebowstąpienia, terminy mówiące o wywyższeniu Jezusa są wielką metaforą interpretującą wydarzenie Zmartwychwstania) oraz droga dla Jego Kościoła. Ukrzyżowany, uznany za przegranego, właśnie na krzyżu - w darze, ofiarowaniu swojego życia - zamanifestował najgłębszy sens ludzkiej egzystencji jako spotkanie Boga i człowieka, jako komunię

Słowa aniołów skierowane do uczniów po Wniebowstąpieniu Jezusa oferują klucz interpretacyjny tego wydarzenia: „Mężowie z Galilei, dlaczego stoicie i wpatrujecie się w niebo? Ten Jezus, wzięty od was do nieba, przyjdzie tak samo, jak widzieliście Go wstępującego do nieba" (Dz 1, 11). Od chwili Zmartwychwstania spotkanie z Jezusem nie polega na patrzeniu w niebo, ale na konfrontacji z rzeczywistością w jej historycznym wymiarze. Aby odnaleźć Jego nową obecność w wydarzeniach życia, konieczne jest nowe spojrzenie. Dlatego, jak poleca w Dziejach wywyższony Chrystus, trzeba pozostać w Jerozolimie i przyjąć dar Ducha Świętego, moc z wysoka, która poprowadzi Kościól w stronę krańców ziemi: „ale gdy Duch Święty zstąpi na was, otrzymacie Jego moc i będziecie moimi świadkami w Jerozolimie i w całej Judei, i w Samarii, i aż po krańce ziemi” (Dz 1, 8). Zadanie i odpowiedzialność Apostołów dotyczy ziemi, a polega na dawaniu świadectwa. Uczniowie zostają posłani, aby głosić Ewangelię o zbawieniu dostępnym w Jezusie Zmartwychwstałym. Otwiera się czas misji Kościoła ${ }^{53}$. Duch Święty uzdalnia do składania świadectwa i ofiarowania życia Jezusa. Zmartwychwstały Pan, pozostający teraz w komunii z Ojcem, daje moc z wysoka, Ducha Świętego. W Duchu można spotkać Jezusa w nowy sposób, bowiem w czasie Jego nieobecności to Duch Święty staje się wielkim protagonistą ${ }^{54}$.

52 Por. A. Contesi, Atti degli Apostoli oggi, s. 47.

53 Jezus Zmartwychwstały zmienia perspektywę proroków. Oni rozumieli zakończenie historii, królestwo Boga, jako moment, w którym narody ze wszystkich stron świata przybędą do Jerozolimy. Jezus zmienia ten kierunek: królestwo realizuje się w pójściu na krańce ziemi, do miejsc uznanych za nieczyste, na terytoria pogan. Nie ma ziemi i środowiska, które mogłoby być obce lub dalekie dla ofiarowanego przez Niego zbawienia.

54

Por. A. Cortesi, Atti degli Apostoli oggi, s. 47. 
Wniebowstąpienie Jezusa jest - według przekazu Dziejów - „w paradoksalny sposób Jego usunięciem się na bok, aby do akcji wkroczyć mogli uczniowie" "55. Staje się też ważnym orędziem nadziei skierowanym do ludzkości na temat sensu losu człowieka.

\subsection{Powszechne braterstwo i komunikacja}

Ostatnia implikacja etyczna rozumiana jako odpowiedź na dar Ducha Świętego, którą wydobyć chcemy z nauczania Łukasza w Dziejach Apostolskich, to uniwersalistyczny charakter orędzia chrześcijańskiego, świadomość daru zbawienia oferowanego całej ludzkości. Nowość Pięćdziesiątnicy nie polega bowiem na mówieniu językami, ale jak pokazaliśmy w przeprowadzonej wyżej analizie, na darze uzdalniającym do wchodzenia w komunikację z innością drugiego. Duch Święty potrafi przeniknąć każdą kulturę, aby słuchano i zrozumiano chrześcijańskie orędzie o wielkich dziełach Boga dokonanych przez Jezusa. Innymi słowy, Duch Pięćdziesiątnicy tworzy Kościół jako wspólnotę, w której darem „z nieba” staje się komunikacja uniwersalna ${ }^{56}$. Ten dar Ducha Świętego otwiera na dialog ${ }^{57}$ i powszechne braterstwo, zapoczątkowuje też nowy etap w historii zbawienia.

Aktualność etycznego przesłania wynikającego z daru Ducha Świętego, której poświęciliśmy ostatni i docelowy punkt artykułu, staje się oczywista, jeżeli krytycznie spojrzymy na współczesne społeczeństwo. W naszym świecie istnieje wiele murów (nowych wieży Babel?), które zostały skonstruowane, aby zachować jeden naród daleko od drugiego. Wystarczy pomyśleć o „murach apartheidu”, o naruszaniu międzynarodowych norm na terytorium Palestyny, albo też o niewidocznych „murach ze szkła”, które są dzisiaj barierami mentalnymi i kulturowymi, trzymaja w separacji ludzi różnych państw oraz miast i stanowią współczesne znaki odrzucenia i wykluczenia.

Historia początków wspólnoty Kościoła opowiedziana przez Łukasza w jego drugiej księdze ma, jak staraliśmy się wykazać, fundamentalne znaczenie dla współczesnych chrześcijan, którzy z niepokojem pytają dziś - podobnie jak kiedyśświadkowie jerozolimskiej Pięćdziesiątnicy - jak żyć i świadczyć o nadziei, która pochodzi z Ewangelii Chrystusa, „Żyjemy w czasach naznaczonych głębokim kryzysem: ekonomicznym, "wizji dotyczącej sensu życia, niepokoju, którego źródłem jest nasza utylitarystyczna kultura "śmierci bliźniego ""58. Dzieje Apostolskie z ich moralnym przesłaniem, jak staraliśmy się wykazać w tym artykule, mogą być wciąż mocnym światłem pozwalającym odczytać szczególne wezwanie Zmartwychwstałego Pana - który wylał Ducha Świętego - skierowane do współczesnych chrześcijan.

\footnotetext{
Tamże, s. 50.

Por. D. Marguerat, Gli Atti degli apostoli, t. 1: 1-12, s. 90.

Por. A. Cortesi, Atti degli Apostoli oggi, s. 93.

Tamże, s. 16.
} 


\section{BIBLIOGRAFIA}

BotTini G.C., Introduzione all'opera di Luca. Aspetti teologici, Milano 2011.

Cantalamessa R., Tajemnica Pięćdziesiątnicy, Wrocław 2002.

Cortesi A., Atti degli Apostoli oggi: una proposta di lettura in un'epoca di crisi, Firenze 2013.

Dyк S., Duch, Stowo, Kościót. Biblijny model ewangelizacji, Lublin 2007.

Jankowski A., Duch Święty Dokonawca zbawienia. Nowy Testament o postannictwie eschatologicznym Ducha Swiętego, Kraków 2003.

Jan Pawee II, Encyklika Dominum et Vivificantem o Duchu Swiętym w życiu Kościoła i świata, Rzym 1986.

Kudasiewicz J., Odkrywanie Ducha Świętego. Medytacje biblijne, Kielce 1998.

Marguerat D., Gli Atti degli apostoli, t. 1: 1-12, Bologna 2011.

Mielcarek K., Żydowskie święto Pięćdziesiątnicy w perspektywie św. Łukasza (Dz 2, 1-41), „Roczniki Teologiczne” 1 (2003), z. 1, s. 67-78.

Pesch R., Die Apostelgeschichte (Apg 1-12) (EKK 5/1), Neukirchen-Vluyn-Zürich 1986.

Rossé G., Atti degli Apostoli commento esegetico e teologico, Roma 1998.

SCALAbRini P.S., Spirito e nuova alleanza nel Primo Testamento, „Parola, spirito e vita” 38 (1998), s. 43-62.

Vidal M., Nuova morale fondamentale. La dimora teologica dell' etica, Bologna 2004.

\section{ABSTRACT}

\section{KrzyszTOF BielińsKi C.Ss.R}

The Gift of the Holy Spirit and its Ethical Implications for the Community of the Church on the Basis of Acts 2:1-41

The article speaks about the significance which the coming of the Holy Spirit had for the early Church. The first part of the text, which focuses on the Pentecost narration (Acts 2:1-13), shows that in the theology of the Acts of the Apostles the phenomenon of the Pentecost marks the moment when the first disciples of the Risen Christ open to a language hitherto unknown to them, to a sign and the outer manifestation of a new heart. Thanks to the outpouring of the Holy Spirit, the community of the disciples became the Church. The gift of the Spirit gave them the creative ability to communicate despite human differences, dissolved the barriers between them 
and brought about their unity. The next three passages of Peter's Pentecostal Sermon (Acts 2:14-41), presenting the theological and redemptive meaning of the Pentecost, are analyzed in the second part of the article. Peter's speech constitutes Luke's interpretation of the phenomenon of the Pentecost which should be understood as the inauguration of a new epoch (Acts 2:15-21), the fruit of Jesus' Passover (Acts $2: 22-36$ ), and the call to respond to the gift "from above" in the act of conversion and through accepting baptism in the name of Jesus (Acts 2:37-41). The third and last part of the article presents three most important ethical implications (in Luke's rendering) which constitute the expected reply of the Risen Lord's disciple to the gift of the Holy Spirit. The essence of the moral message of Luke's Pentecostal narration can be expressed in the following exhortations: to walk the path of good in the footsteps of Jesus anointed with the Holy Spirit; to give witness and to proclaim the Gospel about the redemption available in the Risen Christ; to be open to dialogue and to the brotherhood of all.

Słowa klucze: zesłanie Ducha Świętego, dar, pneumatologia narratywna Łukasza, orędzie etyczne

Keywords: Pentecost, gift, Luke's narrative pneumatology, ethical message 